\title{
16. 腹腔鏡下超音波検查法
}

\section{一その開発，改良と応用—}

(日本医科大学産婦人科学教室)

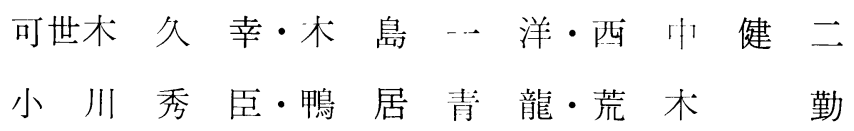

\section{目的}

産婦人科腹腔鏡と超音波は歴史のある検査法で ある.しかし両者を命せた産婦人科腹腔鏡超音波 検査の研究発表は数少ない，我々はこれまで産婦 人科腹腔鏡超音波検査の有用性について数々の報 告をしてきた（1.超音波医学． 17 S. II : 779, 1990，2．日産婦関東悳企報．52：89，1990， 3. 産婦世界。 4 . 3:171，1991)。すなわち腹 腔鏡超音波検相は直視下に色彩を伴う立体的イメ ージで観察し得るといら腹腔鏡検査の利点と断層 面の画像分析といら超音波検査法の利点を同陵に 取入れた検査法である. 今回は新しく開発された 腹腔鏡用超音波探触子と従来の探触子による腹腔 鏡超音波検査法の比較を行ないさらにこの探触子 の開腹手術における有用性について検討した.

\section{超音波器材}

今回用いた腹腔鏡用探触子・は ALOKA-UST5522-7.5(以下 5522), 超音波装置は ALOKA-SSD 650である. 従来の探触子はALOKA-UST-936-7.5 （以下 936），超音波装置はALOKA-SSD620であっ た.

\section{腹腔鏡装置}

フジノンまたはオリンパスの器具を用いた。

\section{結果}

1. 検査施行テクニック：5522 は直径 $1 \mathrm{~cm}$ 㳖さ $405 \mathrm{~mm}$ の硬性棒状の形状で, 腹腔内插入に際して は $11 \mathrm{~mm}$ のトロカールを用いた. 臓器の超音波的
観察は容易に怕来た。一方，936 は経食道用に開 発された探触子のため探触子先端がやや大きく探 触子に命ったトロカールがなかった。 このため 936 の腹空内插入は困難であった。 さらに，936は ファイバー型のため, 腹腔内で探触子の先端の固 定が困難であった。

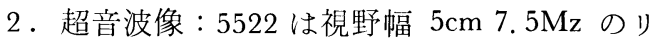
二ア型超音波像を描出する。骨盤臓器の超音波イ メージングは充分に行ない得た. 936は視野幅 $3 \mathrm{~cm}$ 7. $5 \mathrm{Mz}$ のコンベックス型超音波像を描出する. 観 察目的範囲に比べて画像がやや小さい印象を受け た。

3. 臨床有用性：5522 を使用した習慣性流産例 は腹腔鏡観察の範囲では正常子宮の形態であった が，腹腔鏡下超音波検查にて中隔子宮の確定診断 を行ない得た。本例は後日開腹下に子宮形成術を 行ない, 術中に5522を使用し手術を容易に行ない 得た. 936 を用いた子宮内膜症の 2 例では各々子 宮腺筋症に埋没した子宮笳腫と, 腸間膜癒着に埋 没した卵巣を腹腔鏡超音波検査で見出し得た。こ の 2 例は腹腔鏡超音波検査が有用であった。

\section{考察}

腹腔鏡一超音波検査は腹腔鏡検査と超音波検査 の雨者の垃所を取入れ短所を補ら画期的な検查法 である. 特に, 強調すべきことは腹腔鏡検査と超 消波検查を各々独立的に行なって得た所見の綜合 評佂に比べ，腹腔鏡下に超音波検查を行ならこと によって，更に雷要な所見を得ることが出来る点 である。 